\section{Risks of resurrecting 1918 flu virus outweigh benefits}

SIR — Your Special Report ${ }^{\alpha}$ The $1918 \mathrm{flu}$ virus is resurrected ${ }^{\text {" }}$ (Nature 437, 794-795;

2005), on the debate surrounding the recreation of the 1918 (Spanish) human influenza virus, focuses solely on the question of publication, giving little attention to the possibility of regulating potentially harmful experiments before they are started.

A key element of co-operative security is trust and confidence. Only a high level of transparency will enable nations to judge others' intentions correctly, act to discourage unfounded suspicion and build confidence in compliance with arms-control treaties.

Withholding critical information on dualuse research would undermine arms-control efforts. Once a research project has been conducted, it should be published in full. The preferred option for research where potential risks are considered to outweigh potential benefits is to stop the research before it even starts. Both the UK Royal Society and the US National Academy of Sciences have proposed a systematic review of scientific research proposals before workstarts, but this approach is entirely neglected in the debate about the Spanish flu virus. The consequences of this project could, and should, have been assessed ten years ago or at any time since.

Another shortcoming of the current debate is the lack of a systematic approach to risk-benefit analysis. Any intervention in the scientific process should be based on a scientifically sound assessment of both risks and benefits. Criteria to assess the potential misuse of dual-use research include its military usefulness and the level of technical expertise needed to apply this knowledge for malign purposes, taking into account a variety of potential actors. The availability of risk-management tools, such as effective arms-control measures, is also an important factor in risk assessment.

Although most commentators agree that the misuse potential of the Spanish-flu work is comparatively high, it seems that the objective assessment of benefits is the more contentious part of the equation.

Your Special Report claims that the Spanish-flu work increases understanding of virulence and pathogenicity factors, and might contribute to identifying the next pandemic strain or developing appropriate drugs. These general statements hold true for most biomedical research projects. But generalities contribute little to a systematic risk-benefit analysis, which should include an assessment of the importance of the research in a health and humanitarian context, whether alternative research avenues are available and the added value of any particular experimental approach.

Influenza pandemics are an important public-health problem, but it is questionable whether a reconstructed viral strain from 1918 is necessary to address this problem. Hundreds of other influenza strains from the past five decades, varying highly in terms of contagiousness and pathogenicity, provide an abundant research resource for comparative studies. The added value of one additional strain — and thus the concrete benefit of the reconstructed Spanish flu strain - is very limited.

\section{Dr Jan van Aken}

Hamburg Centre of Biological Arms Control, Hamburg University, Falkenried 94, 20251 Hamburg, Germany

\section{Value of high-protein diet is clearer than drawbacks}

SIR — There maybe disagreement about whether the words "scientifically proven" should be used to sell books ("A recipe for trouble Nature 438, 1052; 2005). However, we have published widely on the subject of high-protein diets and our findings are broadly similar to those of other research groups who have shown better health outcomes on this kind of diet (see, for example, D. K. Layman et al. J. Nutr. 133, 411-417; 2003, and A. Due et al. Int. J. Obes. Relat. Metab. Disord. 28, 1283-1290; 2004).

High-protein diets have been criticised for their potential to cause renal and bone disease (J. Eisenstein et al. Nutr. Rev. 60, $189-200 ; 2002)$ and the red-meat component has been linked to colorectal cancer (A. Chao et al. J. Am. Med. Assoc. 293, 172-182; 2005), but the evidence is contradictory.

As The CSIRO Total Wellbeing Diet was for a general readership and covered a range of topics, we did not report an extensive review of the literature on high-protein diets. Our own work has focused not just on reduction of body fat but on reduction of lipids, glucose, insulin and blood pressure and minimization of lean-tissue loss. In our opinion, the highprotein, moderate-carbohydrate approach is superior in all these respects. We do not agree with the view reported in your News story ("Diet book attacked for its high-protein advice" Nature 438, 1060; 2005) that the CSIRO diet could lead to more breast cancer and prostate cancer.

You discuss the support we receive from the Australian meat and dairy industries. These industries funded two out of the five weight-loss studies we have performed with this protocol. These protocols were investigator-devised and controlled; the funding bodies had no input into the reports and papers. Certainly they capitalized on the positive results, as is their right.

Peter Clifton

CSIRO Human Nutrition, PO Box 10041 BC, Adelaide, South Australia 5000, Australia

\section{Saintly helpers at hand in Renaissance hospital art}

SIR - In his Science in Culture article ("A vision of birth" Nature 438, 1084; 2005), Martin Kemp comments on medical allusions in the nativity scene painted by Hugo van der Goes in the fifteenth century. Religious iconography was very important at that time, and the saints present in the painting deserve further comment.

The female figure on the far right with an elaborate white dress represents Saint Elisabeth of Thuringia, a thirteenth-century Hungarian princess who was one of the earliest known founders of a hospital in Europe. She stands next to Mary Magdalene, and is carrying a vase of myrrh, a symbol of healing, which I believe symbolizes the early nursing sciences.

On the far end of the left panel is Saint Anthony the Abbot, founder of the first monastic orders, which ran all hospitals at the time. Next to him, carrying a lance, stands Saint Thomas Didymus ("Doubting Thomas"), who was renowned for his insistence on evidential proof.

These saints made excellent icons for the Renaissance healthcare professionals: doctors, friars and nurses. They are portrayed by van der Goes as equal, in size and importance, to Mary and Joseph and at least twice as large as the donors pictured below.

\section{Piero Dolara}

Department of Pharmacology, Viale Pieraccini6, University of Florence, Italy

\section{Humour of gene names lost in translation to patients}

SIR - The choice of a gene name can have unforeseen consequences in addition to infringement of trademark ("Pokémon blocks gene name" Nature 438, 897; 2005). The quirky sense of humour that researchers display in choosing a gene name often loses much in translation when people facing serious illness or disability are told that they or their child have a mutation in a gene such as Sonic hedgehog, Slug or Pokemon.

As with the acronym CATCH22 (from 'cardiac anomaly, T-cell deficit, defting and hypocalcaemia') for chromosome 22q11.2 microdeletions, which was abandoned because of its no-win connotations (J. Burn J. Med. Genet. 36, 737-738; 1999), researchers need to be mindful when naming genes and syndromes.

Ken Maclean

Developmental Biology Unit,

Victor Chang Cardiac Research Institute,

384 Victoria Road, Darlinghurst,

New South Wales 2010, Australia 